\title{
Effects of Ethacrynic Acid on the Isolated Collecting Tubule
}

\author{
Maurice Abramow \\ From the Laboratory of Experimental Medicine, Queen Elizabeth Medical \\ Foundation and Brugmann Hospital, Free University of Brussels, Belgium
}

A в STRACT Effects of the diuretic ethacrynic acid on osmotic water permeability were investigated in the isolated perfused collecting tubule of the rabbit kidney.

The base-line water permeability of the collecting tubule was not affected when the drug $\left(10^{-4} \mathrm{M}\right)$ alone was added to the bathing medium. Vasopressin alone in the bathing medium $(2,5 \mu \mathrm{U} / \mathrm{ml})$ elicited a significant increase in osmotic water absorption. With vasopressin kept in the bathing medium, the addition of $10^{-5} \mathrm{M}$ ethacrynic acid depressed the hydro-osmotic effect of vasopressin by $50 \%$. This inhibitory effect of low concentrations of ethacrynic acid could be surmounted by high, supramaximal dosage levels of vasopressin.

When $10^{-4} \mathrm{M}$ ethacrynic acid was added to the bathing medium before vasopressin, the hydro-osmotic effect of vasopressin and the diuretic in combination was insignificant.

Dibutyryl adenosine $3^{\prime} 5^{\prime}$-monophosphate $\left(10^{-4}-10^{-2} \mathrm{M}\right)$ alone in the bathing medium significantly increased baseline osmotic water flow, mimicing the effect of antidiuretic hormone. When ethacrynic acid was added together with the nucleotide, the permeability remained at the same high level. Theophylline, like the nucleotide and vasopressin, produced a significant hydro-osmotic effect. The magnitude of this response was not affected by further addition of ethacrynic acid $\left(10^{-4} \mathrm{M}\right)$.

It was concluded that ethacrynic acid is an antagonist of antidiuretic hormone. The antagonism probably occurs at the level of the receptor site of the hormone on the peritubular membrane. Antagonism to circulating antidiuretic hormone may therefore be one of the factors involved in the loss of renal concentrating ability brought about by ethacrynic acid diuresis.

Portions of this work were presented at the Sixth Annual Meeting of the European Society for Clinical Investigation, Scheveningen, The Netherlands, April 1972 (1) and the Fifth International Congress of Nephrology, Mexico City, October 1972 (2).

Received for publication 20 March 1973 and in revised form 24 September 1973.

\section{INTRODUCTION}

The diuretic activity of ethacrynic acid has some unique characteristics (3). The drug depresses free water formation during maximal water diuresis in man (4) and $\operatorname{dog}(5)$. It also abolishes the renal concentrating ability since free water reabsorption $\left(\mathrm{TcH}_{2} \mathrm{O}\right)^{1}$ is reduced to nearly zero (4).

The thick ascending limb of Henle's loop is the only segment of the nephron in which the same $\mathrm{NaCl}$ transport mechanism contributes in a major way to both dilution and concentration. Consequently, it had been concluded that the main action of ethacrynic acid was to inhibit $\mathrm{NaCl}$ transport in this particular segment $(4,5)$. Although ample indirect support for an action on the loop of Henle is documented, there is evidence that all the characteristics of ethacrynic acid diuresis are not necessarily connected with this action. Clearance studies in man (6) and bird (7) and also micropuncture studies in $\operatorname{dog}(8)$ and rat (9) suggest that ethacrynic acid also acts on more proximal portions of the nephron. The loss of renal concentrating ability under ethacrynic acid has also been explained by mechanisms other than diminished transport in Henle's loop (10-12).

In particular, it has been concluded on the basis of clearance studies in man that ethacrynic acid opposes the effects of antidiuretic hormone (ADH) (12). In the present study, the effects of ethacrynic acid on the permeability response to $\mathrm{ADH}$ have been directly evaluated.

In studies involving the whole kidney, it is not possible to eliminate hemodynamic changes induced by ethacrynic acid $(10,11)$ or to control transtubular osmotic gradients. Therefore isolated perfused collecting tubules of the rabbit kidney were used in the present study.

The results suggest that ethacrynic acid significantly impairs the permeability response to $\mathrm{ADH}$.

\footnotetext{
${ }^{1}$ Abbreviations used in this paper: ADH, antidiuretic hormone; dbcAMP, dibutyryl adenosine $3^{\prime}-5^{\prime}$ monophosphate; $\mathrm{T}_{\mathrm{CH}} \mathrm{O}$, free water reabsorption.
} 


\section{METHODS}

The in vitro microperfusion techniques used were essentially those described initially by Burg, Grantham, Abramow, and Orloff (13).

Rabbits of the New Zealand or Dutch strains, weighing $1.5-2 \mathrm{~kg}$, were killed by decapitation. One kidney was rapidly removed and a slice about $2 \mathrm{~mm}$ thick was cut and immersed in a dish of oxygenated Ringer's solution. A segment of cortical collecting tubule was freed by microdissection without any pretreatment. Great care was taken to manipulate only the ends of the tubule and not to overstretch the tubule during dissection. The tubule was then transferred to an incubation cell mounted on the stage of an inverted microscope (Nikon model M, Nikon, Inc., Div. of EPOI, Garden City, N. Y.). Thus it was possible to position, perfuse, and observe the tubule at 40-600 magnification. The lengt? of the tubule exposed to the bathing medium was $1.2-3 \mathrm{~mm}$, as measured at the end of each experiment with a micrometer eyepiece.

The inner concentric micropipette used to perfuse the kidney tubule (13) was connected to a microsyringe pump (Sage Model 255-3, Sage Instruments Div., Orion Research, Inc., Cambridge, Mass.). The pump delivered the perfusion fluid at rates from 8 to $14 \mathrm{nl} / \mathrm{min}$. The outer collecting micropipette was adequately sealed around the tubule end by placing liquid Sylgard 184 (Dow Corning Corp., Midland, Mich.) in the tip of the pipette (14).

The tubules were dissected and incubated at room temperature $\left(24^{\circ} \mathrm{C}\right)$ in a modified Ringer's solution. The Ringer's solution was constantly stirred and oxygenated by bubbling a $95 \% \mathrm{O}_{2}, 5 \% \mathrm{CO}_{2}$ mixture through it. This solution had the following composition: $115 \mathrm{mM} \mathrm{NaCl}, 5 \mathrm{mM}$ $\mathrm{KCl}, 25 \mathrm{mM} \mathrm{NaHCO}_{8}, 10 \mathrm{mM} \mathrm{Na}$ acetate, $1.2 \mathrm{mM} \mathrm{NaH}{ }_{2}$ $\mathrm{PO}_{4}, 1.2 \mathrm{mM} \mathrm{MgSO}, 1.0 \mathrm{mM} \mathrm{CaCl}, 5.5 \mathrm{mM}$ dextrose, and $5 \% \mathrm{vol} / \mathrm{vol}$ calf serum (Microbiological Associates, Inc., Bethesda, Md.). The solution was $290 \mathrm{mosmol} / \mathrm{kg}$.

Transtubular osmotic gradients were imposed by perfusing the tubule with a "hypotonic" Krebs-Ringer-phosphate solution of the following composition: $60 \mathrm{mM} \mathrm{NaCl}, 2.5$ $\mathrm{mM} \mathrm{K} \mathrm{K}_{2} \mathrm{HPO}_{4}, 1.2 \mathrm{mM} \mathrm{MgSO}_{4}$, and $1.0 \mathrm{mM} \mathrm{CaCl}_{2}$. The $\mathrm{pH}$ was adjusted to 7.4 with $\mathrm{HCl}$. Osmolality of the solution was 125 mosmol kg kater. $^{-1}$.

${ }^{125}$ I-radioiodinated serum albumin (RISA II SORIN) was used as a volume marker. Samples of the albumin solution were dialysed against modified Ringer's solution to remove any free ${ }^{125} \mathrm{I}$. The final concentration of the isotope in the perfusion fluid was $15-50 \mu \mathrm{Ci} / \mathrm{ml}$. In later studies, $\left[{ }^{125} \mathrm{I}\right]$ iodothalamate (Glofil-125, Abbott Laboratories, North Chicago, Ill.) was substituted for albumin.

Leak of perfusion fluid into the bathing medium was less than $1 \%$ of the perfusion rate and usually $0.2-0.3 \%$. The true perfusion rate was thus measured as the amount of the volume marker recovered in the collecting pipette during each collection period $(10-25 \mathrm{~min})$, divided by the concentration of the marker in the perfusion fluid. The collection rate was measured as the volume of the fluid collected during that same period, with a calibrated constant bore capillary.

Net water absorption was the difference between the perfusion and collection rate and was expressed in unit of luminal surface and of transtubular osmotic gradient $(\mu 1$ $\mathrm{cm}^{-2} \mathrm{~min}^{-1} \mathrm{osmol}^{-1}$ ) (15). For the purpose of calculation, it was assumed that osmolality in the lumen increased as a result of water absorption without net movement of solutes. The osmolality at the collecting end could then be calculated as the product of the osmolality of the perfusion solution by the concentration index of the volume marker in the collected fluid (15). The mean transtubular osmotic gradient was calculated as the logarithmic mean $(16,17)$ of the osmotic gradient at the perfusing and collecting end.

The reported values for water absorption are the average of two or more steady-state collection periods for each experimental condition.

All test agents were added to the bathing medium. Vasopressin was added as Pitressin (Parke, Davis \& Co., Detroit, Mich.), usually at $2.5 \mu \mathrm{U} / \mathrm{ml}$. The sodium salt of dibutyryl cyclic AMP (dbcAMP) was obtained from Sigma Chemical Co., St. Louis, Mo., and Boehringer \& Söhne, Mannheim, Germany. The dbcAMP was employed at final concentrations in the bathing media of $10^{-4}-10^{-2} \mathrm{M}$. Solutions of theophylline (E. Merck AG, Darmstadt, W. Germany) were employed at a final concentration of $5 \times$ $10^{-3} \mathrm{M}$. Ethacrynic acid, ${ }^{2}$ 2,3-dichloro-4-(2 methylene-butyryl)-phenoxyacetic acid, was dissolved in dilute bicarbonate solution and appropriately diluted in the bathing medium to give final concentrations of $10^{-4}$ and $10^{-5} \mathrm{M}$.

All final media were adjusted to $\mathrm{pH} 7.4$ and to 290 mos$\mathrm{mol} / \mathrm{kg}$ when required.

The radioactivity of the perfusion, the collected fluid, and the bathing media was measured either in a Packard autogamma spectrometer (Packard Instrument Co., Inc., Downers Grove, Ill.), or a Tracerlab manual gamma well counting system (Tracerlab Div., LFE Electronics, Richmond, Calif.). The perfusion samples and collected fluid samples were preset for 10,000 counts.

Statistical comparisons were made with Student's $t$ test for paired data, .unless stated otherwise in the Results section.

\section{RESULTS}

At the start of the perfusion, the tubules are highly permeable to water. The osmotic water flow spontaneously decreases to reach a minimum steady state value after 180-220 min perfusion (control values in Tables I-IV). When vasopressin is added to the bath during the steady state period, a rapid increase in permeability is obtained with a sustained plateau for more than $3 \mathrm{~h}$ (Fig. 1). The increase in water permeability is highly significant (Tables I and III). Tables I and II summarize experiments with relatively large doses of ethacrynic acid $\left(10^{-4}-10^{-3} \mathrm{M}\right)$. In Table III smaller doses $\left(10^{-5} \mathrm{M}\right)$ of ethacrynic acid and vasopressin $(2.5 \mu \mathrm{U} / \mathrm{ml})$ were used. When the tubules are in a vasopressin bathing fluid, the addition of ethacrynic acid significantly depresses the hydro-osmotic effect of vasopressin (Table I, II, III and Fig. 2). In contrast, in control experiments with vasopressin alone $(2.5 \mu \mathrm{U} / \mathrm{ml})$ water permeability did not decline when incubation was extended over the same length of time as was required to elicit the inhibitory effect of ethacrynic acid (mean difference between late periods and steady state periods $+0.898 \pm 0.42$ SEM, $n=8, P>0.05$, as opposed to $-4.31 \pm 1.32, P<0.01$ in Table III, column C-B).

${ }^{2}$ A gift of Merck, Sharp and Dohme, West Point, $\mathrm{Pa}$. 


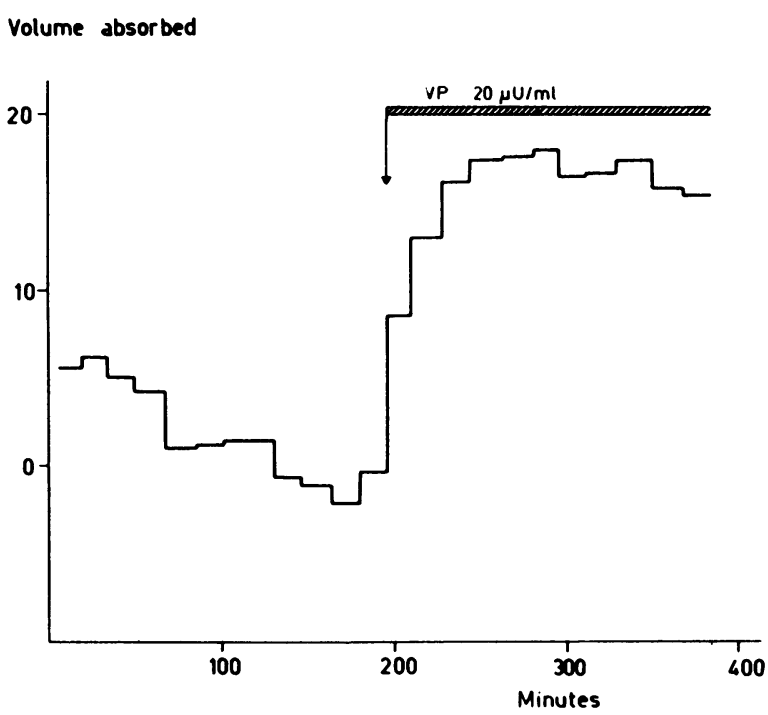

Figure 1 Effect of vasopressin (VP) on osmotic water permeability. Hormone was added to the bath when water permeability has reached steady state. Volume absorbed is in $\mu 1 \mathrm{~cm}^{-2}$ osmol-1 $\mathrm{min}^{-1}$.

Fig. 2 depicts one typical experiment: the tubule responded to as little as $0.25 \mu \mathrm{U} / \mathrm{ml}$ of vasopressin. When $2.5 \mu \mathrm{U} / \mathrm{ml}$ was added a further increase in permeability resulted. The addition of ethacrynic acid produced an immediate drop in water flow, which was reversible after the concentration of vasopressin had been increased to $2 \mathrm{mU} / \mathrm{ml}$. In preliminary experiments, mere removal of the diuretic from the bathing medium was not followed by the restoration of the tubule's initial responsiveness to vasopressin.

When ethacrynic acid was added alone (Fig. 3, Table II), it produced no change in water flow. Subse- quent addition of vasopressin produced only a small increase in permeability. The increase was not statistically significant. Subsequent removal of only the diuretic produced a further, insignificant increase in water flow. However, if the periods with vasopressin after removal of ethacrynic acid are compared with the periods immediately before the addition of vasopressin, a significant hydro-osmotic effect of the hormone is still demonstrable. The mean response of two series of tubules (Table II, column C-B, and Table III, column B-A) can be compared by simple Student's $t$ test. They show that the hydro-osmotic response of the vasopressin-ethacrynic acid combination is significantly smaller that that of vasopressin alone $(P<0.01)$.

Similarly, the mean vasopressin response after removal of ethacrynic acid (Table II, column D-B) is significantly smaller than in the experiments where the tubules had not previously been in contact with the drug (Table III, column B-A) $(P<0.05)$. Fig. 3 shows that, after an incubation with $10^{-4} \mathrm{M}$ ethacrynic acid, increasing the concentration of the hormone 100 times did not improve the response. The results indicate that preincubation of the tubules with ethacrynic acid seriously impairs their hydro-osmotic response to vasopressin. They further suggest that the effects of ethacrynic acid are not entirely reversible during the time course of these experiments.

Vasopressin is thought to exert its effect through intracellular accumulation of cAMP $(18,19)$. In the present studies, the hydro-osmotic effect of the dbcAMP was similar to that of vasopressin (Table IV). No clear dose-response relationship of the nucleotide alone was apparent between $10^{-4} \mathrm{M}$ and $10^{-2} \mathrm{M}$. Therefore, all results of experiments with dbcAMP were averaged, irrespective of the concentration of the nucleotide

TABLE I

Effect of Ethacrynic Acid on Vasopressin Response

\begin{tabular}{|c|c|c|c|c|c|}
\hline Exp & $\underset{\text { Control }}{\text { A }}$ & $\begin{array}{c}\text { B } \\
\text { Vasopressin } \\
(\mu \mathrm{U} / \mathrm{ml})\end{array}$ & $\begin{array}{l}\text { C } \\
\text { Vasopressin } \\
\text { plus } \\
\text { ethacrynic } \\
\text { acid (M) }\end{array}$ & $\begin{array}{c}B-A \\
\text { Vasopressin } \\
\text { effect }\end{array}$ & $\begin{array}{c}\mathrm{C}-\mathrm{B} \\
\text { Ethacrynic } \\
\text { acid effect }\end{array}$ \\
\hline \multicolumn{6}{|c|}{$\mu \mathrm{l} \mathrm{cm}-2 \min ^{-1} o s m o l^{-1}$} \\
\hline 1 & 7.50 & $10.05(20)$ & $8.76\left(5 \times 10^{-4}\right)$ & 2.55 & -1.29 \\
\hline 2 & -1.15 & $18.60(10)$ & $11.64\left(10^{-3}\right)$ & 19.75 & -6.96 \\
\hline 3 & 1.82 & $13.32(10)$ & $9.03\left(10^{-4}\right)$ & 11.50 & -4.29 \\
\hline 4 & -0.40 & $16.90(20)$ & $12.48\left(10^{-3}\right)$ & 17.30 & -4.42 \\
\hline 5 & 4.49 & $13.61(10)$ & $10.45\left(10^{-4}\right)$ & 9.12 & -3.16 \\
\hline Mean & 2.45 & 14.50 & 10.47 & 12.04 & -4.02 \\
\hline \multirow[t]{2}{*}{$\mathrm{SE}$} & \pm 1.60 & \pm 1.49 & \pm 0.72 & \pm 3.05 & \pm 0.92 \\
\hline & & & & $P<0.02$ & $P<0.02$ \\
\hline
\end{tabular}

Values in columns $\mathrm{A}$ to $\mathrm{C}$ are absolute net water flows.

The last two columns refer to differences in water absorption. 
TABLE II

Effect of Ethacrynic Acid and Vasopressin on Osmotic Water Flow

\begin{tabular}{|c|c|c|c|c|c|c|c|c|}
\hline Exp & $\underset{\text { Control }}{\text { A }}$ & $\begin{array}{c}\text { B } \\
\text { Ethacrynic } \\
\text { acid } 10^{-4} \mathrm{M}\end{array}$ & $\begin{array}{c}\mathrm{C} \\
\text { Ethacrynic } \\
\text { acid plus } \\
\text { vasopressin } \\
(2.5 \mu \mathrm{U} / \mathrm{ml})\end{array}$ & $\begin{array}{c}\mathrm{D} \\
\text { Vasopressin } \\
2.5 \mu \mathrm{U} / \mathrm{ml}\end{array}$ & B - A & $C-B$ & $D-C$ & $D-B$ \\
\hline \multicolumn{9}{|c|}{$\mu l \mathrm{~cm}^{-2} \mathrm{~min}^{-1} o_{s m o l}^{-1}$} \\
\hline $8 \ddagger$ & 3.05 & 2.96 & 3.68 & 4.10 & -0.09 & 0.72 & 0.42 & 1.14 \\
\hline $9 \ddagger$ & 1.63 & $1.50^{*}$ & $5.12^{*}$ & 6.67 & -0.13 & 3.62 & 1.55 & 5.17 \\
\hline 37 & 2.23 & 2.38 & 1.46 & 5.81 & 0.15 & -0.92 & 4.35 & 3.43 \\
\hline 38 & 5.24 & 5.45 & 5.51 & 4.57 & 0.21 & 0.06 & -0.94 & -0.88 \\
\hline 39 & 2.82 & 2.37 & 3.06 & 3.21 & -0.45 & 0.69 & 0.15 & 0.84 \\
\hline 40 & 4.08 & 3.57 & 7.99 & 9.26 & -0.51 & 4.42 & 1.27 & 5.69 \\
\hline 41 & 2.35 & 1.72 & 9.42 & 12.57 & -0.63 & 7.70 & 3.15 & 10.85 \\
\hline Mean & 3.06 & 2.85 & 5.18 & 6.60 & -0.21 & 2.33 & 1.42 & 3.75 \\
\hline \multirow[t]{2}{*}{$\mathrm{SE}$} & \pm 0.46 & \pm 0.51 & \pm 1.05 & \pm 1.25 & \pm 0.12 & \pm 1.15 & \pm 0.69 & \pm 1.49 \\
\hline & & & & & $P>0.10$ & $P>0.05$ & $P>0.05$ & $P<0.05$ \\
\hline
\end{tabular}

Ethacrynic acid was added after the initial control period and vasopressin added subsequently. In column $\mathrm{D}$ are the periods with vasopressin after removal of the diuretic.

Values in columns $\mathrm{A}$ to $\mathrm{D}$ are absolute net water flows.

The last four columns refer to differences in water absorption.

B - A, ethacrynic acid effect; C - B, vasopressin effect in the presence of ethacrynic acid; D - C, residual vasopressin effect after removal of ethacrynic acid; D - B, overall vasopressin effect.

* Ethacrynic acid $10^{-5} \mathrm{M}$ in this experiment.

$\ddagger$ Vasopressin concentration $10 \mu \mathrm{U} / \mathrm{ml}$ in experiments 8 and 9 .

TABLE III

Effect of Low Concentrations of Ethacrynic Acid $\left(10^{-5} M\right)$ on the Permeability

Response to Vasopressin $(2.5 \mu \mathrm{U} / \mathrm{ml})$

\begin{tabular}{|c|c|c|c|c|c|}
\hline $\operatorname{Exp}$ & $\underset{\text { Control }}{\text { A }}$ & $\begin{array}{c}\text { B } \\
\text { Vasopressin }\end{array}$ & $\begin{array}{c}\text { C } \\
\text { Vasopressin } \\
\text { plus } \\
\text { ethacrynic } \\
\text { acid }\end{array}$ & $\begin{array}{c}\text { B - A } \\
\text { Vasopressin } \\
\text { effect }\end{array}$ & $\begin{array}{c}C-B \\
\text { Ethacrynic } \\
\text { acid effect }\end{array}$ \\
\hline \multicolumn{6}{|c|}{$\mu l \mathrm{~cm}^{-2} \min ^{-1}$ osmol-1 } \\
\hline 10 & 2.91 & $23.04^{*}$ & 21.05 & 20.13 & -1.99 \\
\hline 11 & 2.81 & 12.29 & 13.94 & 9.48 & 1.65 \\
\hline 12 & 4.79 & 9.80 & 4.82 & 5.01 & -4.98 \\
\hline 13 & 8.65 & 21.18 & 13.81 & 12.53 & -7.37 \\
\hline 14 & 7.51 & 10.37 & 8.40 & 2.86 & -1.97 \\
\hline 15 & 1.64 & 15.02 & 12.86 & 13.38 & -2.16 \\
\hline 16 & 9.03 & 11.35 & 4.57 & 2.32 & -6.78 \\
\hline 17 & 9.45 & 24.40 & 9.19 & 14.95 & -15.21 \\
\hline 18 & 4.26 & 11.89 & 8.51 & 7.63 & -3.38 \\
\hline 19 & 4.70 & 13.92 & 11.51 & 9.22 & -2.41 \\
\hline 20 & 1.62 & 6.12 & 3.32 & 4.50 & -2.8 \\
\hline Mean & 5.22 & 14.49 & 10.18 & 9.27 & -4.31 \\
\hline \multirow[t]{2}{*}{$\mathrm{SE}$} & \pm 0.89 & \pm 1.78 & \pm 1.56 & \pm 1.68 & \pm 1.32 \\
\hline & & & & $P<0.001$ & $P<0.01$ \\
\hline
\end{tabular}

* Vasopressin, $10 \mu \mathrm{U} / \mathrm{ml}$.

Columns $\mathrm{A}$ to $\mathrm{C}$ are absolute net water flows.

Columns $B-A$ and $C-B$ are differences in water flows. 


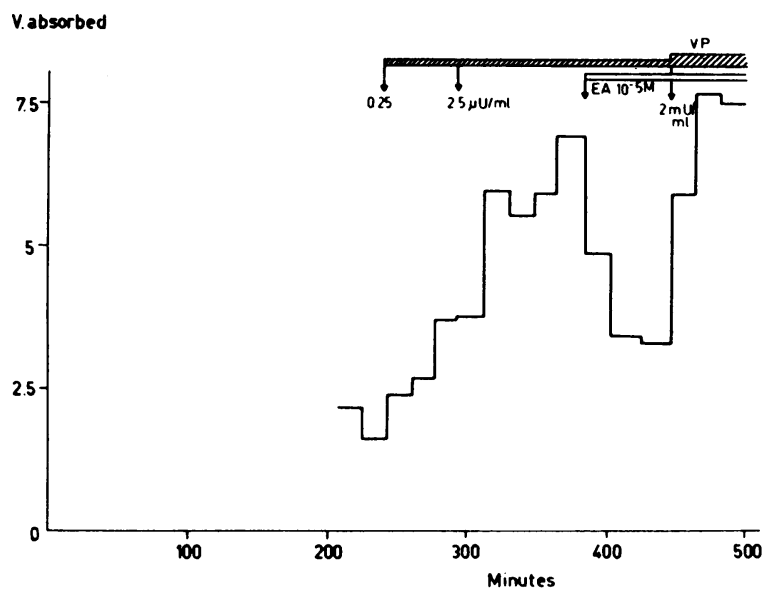

Figure 2 Effect of ethacrynic acid (EA) $\left(10^{-5} \mathrm{M}\right)$ on permeability response to vasopressin (VP) $(2.5 \mu \mathrm{U} / \mathrm{ml})$. Effect of larger doses of vasopressin $(2 \mathrm{mU} / \mathrm{ml})$ on permeability response in the presence of ethacrynic acid. Volume absorbed is as in Fig. 1.

(which was, however, constant throughout an experiment). It is noteworthy that, under $10^{-2} \mathrm{M}$ dbcAMP ( $\mathrm{Ta}-$ ble IV, exp 21-25) water permeability was still slightly, but significantly $(P<0.02)$ increasing during period $\mathrm{C}$. This increase was not felt to be due to any synergistic effect of ethacrynic acid, which was added during period C. Rather, it was suspected that a true maximum steady state level of water permeability had not been reached yet in period $\mathrm{B}$. Therefore, in experiments $26-30$, one or

\section{V. absorbed}

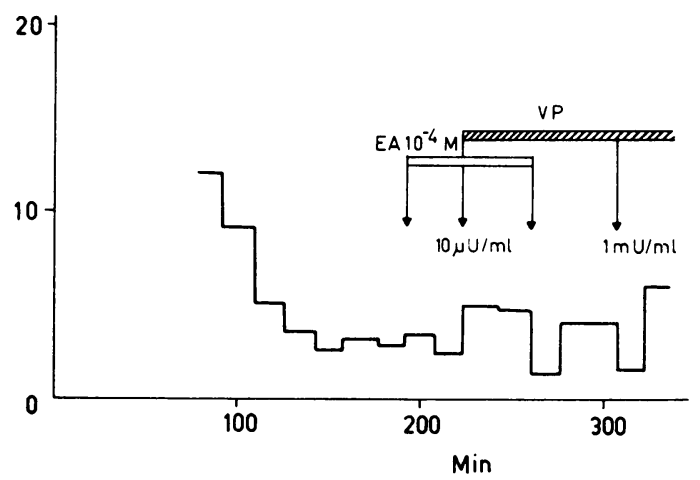

FIGURE 3 Effect of ethacrynic acid $\left(10^{-4} \mathrm{M}\right)$ on steady state osmotic water permeability. Effect of vasopressin during and after ethacrynic acid $\left(10^{-4} \mathrm{M}\right)$. Volume absorbed is as in Fig. 1.

more additional collections were made during period B (to better approach the steady state plateau). A "postdiuretic" period with the nucleotide alone was also tested in these studies (column D). The values with the diuretic present were not statistically different from those in any period with the nucleotide alone. Moreover, the permeabilities during the pre and post-diuretic periods with the nucleotide alone were not significantly different from each other. Also, when all the experiments with dbcAMP were grouped together, no definite

TABLE IV

Effect of Ethacrynic Acid on dbc AMP Response

\begin{tabular}{|c|c|c|c|c|c|c|}
\hline Exp & $\begin{array}{c}\text { A } \\
\text { Control }\end{array}$ & $\begin{array}{c}\text { B } \\
\text { dbcAMP } \\
\text { (M) }\end{array}$ & $\begin{array}{c}\text { C } \\
\text { dbcAMP } \\
\text { plus } \\
\text { ethacrynic } \\
\text { acid } \\
\left(10^{-5} \mathrm{M}\right)\end{array}$ & $\begin{array}{c}\mathrm{D} \\
\text { dbcAMP } \\
\text { (concentration } \\
\text { as in B) }\end{array}$ & $\mathrm{B}-\mathrm{A}$ & $C-B$ \\
\hline \multicolumn{7}{|c|}{$\mu l \mathrm{~cm}^{-2} \mathrm{~min}^{-1}$ osmol $^{-1}$} \\
\hline 21 & 4.72 & $12.14\left(10^{-2}\right)$ & 14.67 & & 7.42 & 2.53 \\
\hline 22 & 3.46 & $13.61\left(10^{-2}\right)$ & 14.44 & & 10.15 & 0.83 \\
\hline 23 & 0.75 & $11.49\left(10^{-2}\right)$ & 12.50 & & 10.74 & 1.01 \\
\hline 24 & 0.72 & $3.63\left(10^{-2}\right)$ & 7.39 & & 2.91 & 3.76 \\
\hline 25 & 1.90 & $4.53\left(10^{-2}\right)$ & 6.99 & & 2.63 & 2.46 \\
\hline 26 & 2.65 & $23.46\left(5 \times 10^{-4}\right)$ & 22.90 & 13.45 & 20.81 & -0.56 \\
\hline 27 & 1.26 & $3.48\left(10^{-4}\right)$ & 3.78 & 4.59 & 1.92 & 0.30 \\
\hline 28 & 1.61 & $5.84\left(2 \times 10^{-4}\right)$ & 5.60 & 5.10 & 4.23 & -0.24 \\
\hline 29 & 0.30 & $4.08\left(2 \times 10^{-4}\right)$ & 2.76 & 2.84 & 3.78 & -1.32 \\
\hline 30 & 3.43 & $5.00\left(5 \times 10^{-4}\right)$ & 4.96 & 4.83 & 1.57 & -0.04 \\
\hline Mean & 2.08 & 8.73 & 9.60 & 6.16 & 6.62 & 0.87 \\
\hline \multirow[t]{2}{*}{$\mathrm{SE}$} & \pm 0.46 & \pm 2.04 & \pm 2.01 & \pm 1.86 & \pm 1.89 & \pm 0.50 \\
\hline & & & & & $P<0.01$ & $0.1<P<0.2$ \\
\hline
\end{tabular}

Column A to $\mathrm{D}$ refer to absolute net water flows. Last two columns refer to differences in water flow. Column D is water flow under dbcAMP after removal of ethacrynic acid. 
TABLE V

Effect of Ethacrynic Acid on Theophylline Response

\begin{tabular}{|c|c|c|c|c|c|}
\hline Exp & $\underset{\text { Control }}{\text { A }}$ & $\begin{array}{c}\text { B } \\
\text { Theophylline } \\
\left(5 \times 10^{-3} \mathrm{M}\right)\end{array}$ & $\begin{array}{c}\mathrm{C} \\
\text { Theophylline } \\
\text { plus } \\
\text { ethacrynic } \\
\text { acid } \\
\left(10^{-4} \mathrm{M}\right)\end{array}$ & B - A & $C-B$ \\
\hline \multicolumn{6}{|c|}{$\mu l \mathrm{~cm}^{-2} \mathrm{~min}^{-1}$ osmol ${ }^{-1}$} \\
\hline $31^{*}$ & 4.39 & 11.86 & - & 7.47 & - \\
\hline 32 & 1.89 & 4.58 & 6.12 & 2.69 & 1.54 \\
\hline 33 & -1.83 & 5.78 & 6.56 & 7.61 & 0.78 \\
\hline 34 & -0.16 & 5.20 & 5.58 & 5.36 & 0.38 \\
\hline 35 & 3.38 & 4.60 & 4.37 & 1.22 & -0.23 \\
\hline 36 & 3.04 & 6.74 & 6.42 & 3.7 & -0.32 \\
\hline Mean & 1.79 & 6.46 & 5.81 & 4.68 & 0.43 \\
\hline \multirow[t]{2}{*}{$\mathrm{SE}$} & \pm 0.96 & \pm 1.13 & \pm 0.40 & \pm 1.06 & \pm 0.34 \\
\hline & & & & $P<0.01$ & $0.2<P<0.3$ \\
\hline
\end{tabular}

* In experiment 31 , ethacrynic acid was omitted.

change in permeability could be attributed to ethacrynic acid.

Theophylline is known to inhibit phosphodiesterase, thereby retarding the degradation of intracellular cAMP (19). In the present study, theophylline also produced a significant hydro-osmotic effect (Table V and Fig. 4). This effect was not altered by ethacrynic acid even at $10^{-4} \mathrm{M}$.

\section{DISCUSSION}

These studies confirm previous observations that vasopressin accelerates osmotic water flow in isolated collecting tubule $(15,17,20)$. Interestingly, although the strains of rabbits and lots of vasopressin may have been different, the mean value of steady state water absorption with similar doses of vasopressin is indistinguishable from that reported by Grantham and Orloff (15). The lowest level of sensitivity to the hormone is also identical: $0.25 \mu \mathrm{U} / \mathrm{ml}$. The theophylline effect (15) was also confirmed. The present study shows that the dbcAMP produces a hydro-osmotic effect similar to that of cyclic AMP (15). This can be achieved with concentrations down to $10^{-4} \mathrm{M}$.

Ethacrynic acid, although ineffective by itself, exerts a clear-cut depression of vasopressin-induced osmotic water flow. Levels of the diuretic down to $10^{-5} \mathrm{M}$ reduce the hydro-osmotic effect of submaximal doses of the hormone by $50 \%$ (Table III). The ethacrynic acidvasopressin antagonism found here in the isolated collecting tubules is consistent with findings on the toad bladder $(21,22)$. With our preparation, as with the toad bladder (22), the effect was not entirely reversible except when "large" doses of vasopressin were applied in the presence of "small" dose of ethacrynic acid (Fig- ure 2). This indicates that the diuretic is effective on the tissue and is not merely inactivating the hormone in the bathing medium. In terms of molar concentration the large doses of vasopressin $(2 \mathrm{mU} / \mathrm{ml})$ used to counteract the effect of the diuretic, are equivalent to $4 \times 10^{-8} \mathrm{M}$. This suggests that the tubule cells retain a considerable affinity for the hormone as compared to ethacrynic acid.

In order to explore the possibility of competitive antagonism between ethacrynic acid and vasopressin, more data than are provided by this study would be needed. A competitive antagonism study would demand detailed analysis of dose-response curves with vasopressin in the presence of several concentrations of etha-

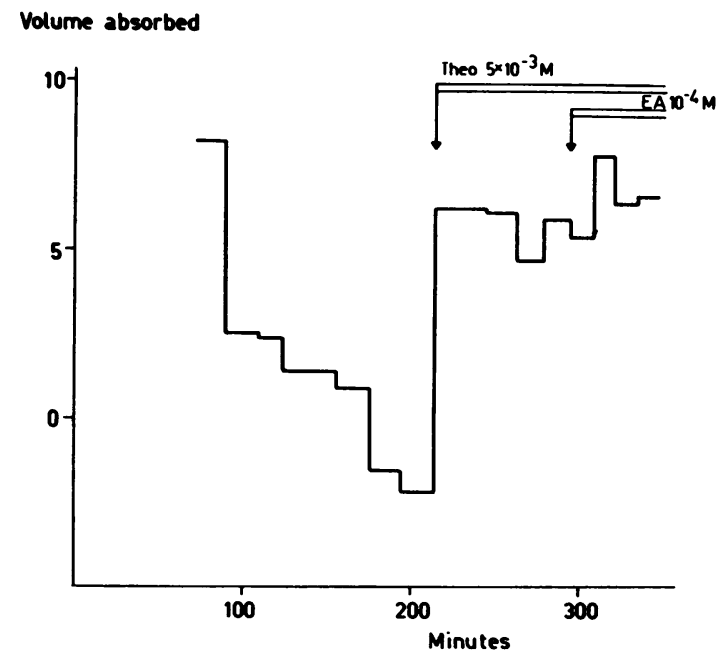

Figure 4 Effect of ethacrynic acid on the permeability response to theophylline. Volume absorbed is as in Fig. 1. 
crynic acid. This type of study, carried out by Bentley on the toad bladder (22), offered suggestive evidence that ethacrynic acid is a competitive inhibitor of vasopressin action.

In order to gain more insight into the mechanism by which ethacrynic acid interferes with hormonal action, we tested the effect of the drug on the tubule responses to theophylline and dbcAMP. Any antagonist of vasopressin that slows the rate of generation of cAMP (by inhibiting the enzyme adenyl cyclase) would be expected to interfere also with the response of the tissue to theophylline. ${ }^{3}$ The response of the tubule to exogenous cAMP, however, would not be affected by such an antagonist. Inhibition of cyclic AMP response would be expected only if the vasopressin antagonist influenced steps in permeability response subsequent to cyclic AMP accumulation. On the other hand, any vasopressin antagonist that affects neither cyclic AMP nor theophylline response probably acts before adenyl cyclase activation. Such appears to be the case with respect to ethacrynic acid. The diuretic probably acts at the level of the hormone receptor, without affecting the basal activity of the enzyme. Consistent with this view is the fact that the diuretic does not inhibit the theophylline response. Also it does not decrease osmotic water flow by itself. However, not much weight should be given to the latter point, since the level of water absorption without $\mathrm{ADH}$ is so low and variable that a sizable effect of ethacrynic acid alone might be missed. Similar conclusions with respect to the mechanisms underlying the ethacrynic acid-vasopressin interaction were derived from studies on the toad bladder $(21,22)$.

In contrast to the inferences from our findings, ethacrynic acid from 2 to $5 \times 10^{-4} \mathrm{M}$ has been shown to depress basal as well as hormone-stimulated adenylcyclase activity in membrane preparations from cortex and medulla of rat kidney (23). It must be stressed, however, that results of biochemical studies with disrupted cell preparations are not necessarily relevant to findings obtained with the intact cell system we used, in which a physiological response is measured. For example, the concentrations of hormone required to stimulate adenyl cyclase in the membrane preparation (23) was $2.5 \times 10^{-6} \mathrm{M}$ as compared to only $5 \times 10^{-12} \mathrm{M}$ to accelerate osmotic water flow in our studies. It is believed that in membrane preparations, drug access to an "unprotected" active site of the enzyme is made possible, whereas the affinity of the hormone for the receptor is decreased.

Ethacrynic acid interferes with sodium chloride transport in a variety of tissues (24-27). The inhibitory ef-

\footnotetext{
${ }^{\mathbf{3}}$ Theophylline indeed inhibits cyclic nucleotide phosphodiesterases, thereby permitting accumulation of intracellular cAMP through basal activity of adenyl cyclase $(18,19)$.
}

fect of the diuretic on ADH-induced water flow in the collecting tubule might thus conceivably be dependent on reduced water movement coupled to net sodium reabsorption. This is unlikely, however. Except at extremely slow perfusion rates (27), the isolated collecting tubule net fluid absorption is negligible in the absence of an osmotic gradient, with or without ADH present (16). Moreover, this study shows that, in the absence of $\mathrm{ADH}$ ethacrynic acid does not modify water absorption. In addition, we have observed (2) that ethacrynic acid produces no change in the transtubular electrical potential difference, which is associated with an active sodimm transport mechanism in this segment of the nephron (28). However, ethacrynic acid did blunt the increase in potential difference brought about by the hormone (2).

All the effects of ethacrynic acid we have observed are thus compatible with the view that the drug is reacting with some membrane component at the external face of the peritubular membrane. Although the drug may penetrate the cell interior and produce other metabolic changes, transmembrane passage is not required to account for our observations.

It is tempting to speculate that the drug specifically binds to some hormone receptor-reactive groups. These groups could be similar to components of a pump or leak system involved in $\mathrm{NaCl}$ translocation in other segments of the nephron, such as the thick ascending limb of Henle's loop. Perhaps these groups would be nothing more than - $\mathrm{SH}$ groups since ethacrynic acid is a strong $\mathrm{SH}$ reagent (3). However, the question appears more complicated, since in preliminary studies we found that furosemide (another so-called "loop diuretic"), which is devoid of - $\mathrm{SH}$ combining activity, also interferes with the hydro-osmotic effect of vasopressin in the collecting tubule (29). In addition, analogues of ethacrynic acid with little or no - SH-combining activity behave as antagonists of vasopressin in the toad bladder (22).

The results of our study suggest that during ethacrynic acid diuresis, circulating ADH may become less effective on its renal target. Extrapolation from in vitro studies to the in vivo situation must be done with great caution, however. The effective concentrations of the drug used here are low compared to most in vitro studies (23-25). However, it is not certain if these concentrations are comparable to the effective dose in the pertinent regions of the kidney during diuresis (30). It should not be construed as evidence against the occurrence of a drug- $\mathrm{ADH}$ antagonism in vivo because complete reversal of the drug effect is not achieved within the duration of the experiment. Indeed, the time course of recovery from the ethacrynic acid diuresis is insufficiently documented to decide about the validity of extrapolation on these grounds. 
It is doubtful however that the hormone receptors, which in this intact cell system seem to respond to $A D H$ in the same manner as in vivo, would be insensitive to the drug during diuresis.

A prerequisite for the translation of a difference in water permeability of the collecting tubule into changes in urine flow and tonicity is the maintenance of a driving force for transtubular water transfer, i.e. an osmotic gradient. Since the nephron segment studied is a cortical segment, a transtubular osmotic gradient would only exist in vivo if the fluid entering the collecting tubule were dilute relative to the plasma. No direct data pertaining to osmotic equilibration under $\mathrm{ADH}$ influence along the distal tubule were available in the rabbit. However, it is reasonable to assume that fluid entering the cortical collecting tubule is dilute in hydropenia as well as in water diuresis, since the rabbit distal convoluted tubule is very short. In addition, highly sensitive hormone receptors in the cortical collecting tubule would be apparently useless during hormone action were the fluid perfusing this segment isotonic to the peritubular blood.

It is thus possible that a major portion of the water reabsorption in the rabbit cortex during hydropenia takes place in the collecting tubule itself because of the existence of a transtubular osmotic gradient similar to that created in the experiments.

Ethacrynic acid, by interfering with dilution in the ascending limb of Henle's loop, would be expected to diminish any osmotic gradient generated at this level. However, clearance studies have shown that ethacrynic acid does not entirely abolish free water generation at or beyond the loop $(4,5)$.

Thus any fraction of free water that would remain unabsorbed in the cortical collecting tubule because of antagonism between the drug and $\mathrm{ADH}$ would result in augmented flow of urine with lower osmolality.

If the ethacrynic acid-ADH antagonism found in the cortical portion of the collecting system also applies to the medullary portion (a likely hypothesis), then the driving force for net transtubular water transfer is the hypertonicity of medullary interstitium. Experimental evidence has been obtained in the dog that the corticomedullary gradient for $\mathrm{Na}$ and urea is completely obliterated after ethacrynic acid infusion (31). However, diminished rather than suppressed gradients have also been observed (32). If such is the case during hydropenia in the rabbit, then the diuretic-ADH interaction may be affecting water excretion through an effect at the level of the medullary collecting duct as well.

Washout of the medullary solutes under ethacrynic acid has been attributed exclusively to inhibition of the function of the thick ascending limb of Henle's loop (31). The present study would suggest also that an additional factor may be operative. If during ethacrynic acid diuresis the collecting system becomes less sensitive to $\mathrm{ADH}$, the pattern of solute distribution in the concentrating kidney may be shifted towards that of a kidney undergoing water diuresis. In the latter situation a decrease in medullary osmolality is well known (33).

The loss of renal concentrating ability cannot be ascribed exclusively to insensitivity to circulating $\mathrm{ADH}$ because, if this were the only mechanism involved, the urine should be hypotonic, whereas it is isotonic to the blood in most clearance studies (4). In some other studies, also conducted during hydropenia, $\mathrm{TcH}_{2} \mathrm{O}$ can become negative $(5,6,12)$, although free water excretion is small. Several explanations may be offered for these findings. The hypothesis can be formulated that during ethacrynic acid diuresis and maximal stimulation of $\mathrm{ADH}$ secretion, the kidney undergoes changes some of which are comparable to those experimentally created by Orloff, Wagner, and Davidson (34). They produced solute (isotonic mannitol) diuresis in the presence of several dosage levels of exogenous vasopressin and found the final urine to be iso-, hypo-, or hypertonic depending on the rate of solute excretion and the vasopressin dosage. It appears that in the case of ethacrynic acid diuresis the "effective" concentration of $\mathrm{ADH}$ should be considered, owing to altered sensitivity of the hormone receptors.

Clearly, interplay between several parameters, including ability to generate free water, transtubular osmotic gradients, permeability to water of the collecting system, and extent of osmotic equilibration in the collecting duct (rate of solute excretion), will determine the volume and tonicity of the final urine. It is difficult, however, to evaluate the relative importance of each of these parameters with the data available.

It is apparent that the more depressed the solute transport in the loop, the less the drug-ADH antagonism will influence water excretion. On the other hand, the measurement of $\mathrm{TcH}_{2} \mathrm{O}$, particularly in ethacrynic acid diuresis, should not permit quantitative evaluation of solute transport in the loop.

In conclusion, inhibition of salt transport in the ascending limb of Henle's loop doubtless accounts for the potent natriuretic effect of ethacrynic acid. This adequately explains the observed decrease in free water clearance and at least some portion of the depression of $\mathrm{TCH} 2 \mathrm{O}$. The results of the present study suggest that antagonism with $\mathrm{ADH}$ is an additional factor that may depress renal concentrating ability.

\section{ACKNOWLEDGMENTS}

The author is grateful to Dr. Jack Orloff for critically reviewing the manuscript.

The technical assistance of Mrs. Suzanne Foulon is acknowledged. This investigation was supported by the Fonds de la Recherche Scientifique Médicale, contract $\mathrm{N}^{\circ}$ 1178. 


\section{REFERENCES}

1. Abramow, M. 1972. Effects of ethacrynic acid on the permeability response of the isolated collecting tubule to vasopressin, cyclic AMP and theophylline. Eur. J. Clin. Invest. 2 : 269a. (Abstr.)

2. Abramow, M. 1972. Effects of ethacrynic acid on osmotic water permeability and transtubular potential difference in the isolated rabbit collecting tubule. Proc. Int. Cong. Nephrol. 5: 35. (Abstr. 149)

3. Beyer, K. H., J. E. Baer, J. K. Michaelson, and H. E. Russo. 1965. Renotropic characteristics of ethacrynic acid: a phenoxyacetic saluretic-diuretic agent. J. Pharmacol. Exp. Ther. $147: 1$.

4. Goldberg, M., D. K. McCurdy, E. L. Foltz, and L. W. Bluemle, Jr. 1964. Effects of ethacrynic acid (a new saluretic agent) on renal diluting and concentrating mechanism: evidence for site of action in the loop of Henle. J. Clin. Invest. 43: 201.

5. Earley, L. E., and R. M. Friedler. 1964. Renal tubular effects of ethacrynic acid. J. Clin. Invest. 43: 1495.

6. Flanigan, W. J., and G. L. Ackerman. 1966. Site of action of ethacrynic acid. Arch. Intern. Med. 118: 117.

7. Nechay, B. R. 1967. Renal effect of ethacrynic acid in chickens, a species with a small counter-current system. J. Pharmacol Exp. Ther. $158: 471$.

8. Clapp, J. R., G. A. Nottebohm, and R. R. Robinson. 1971. Proximal site of action of ethacrynic acid: importance of filtration rate. Am. J. Physiol. 220: 1355.

9. DiBona, G. F. 1971. Micropuncture studies on the site of action of ethacrynic acid in the rat. J. Pharmacol. Exp. Ther. $176: 255$.

10. Birtch, A. G., R. M. Zakheim, L. G. Jones, and A. C. Barger. 1967. Redistribution of renal blood flow produced by furosemide and ethacrynic acid. Circ. Res. 21: 869.

11. Epstein, M., N. K. Hollenberg, R. D. Guttmann, M. Conroy, R. I. Basch, and J. P. Merrill. 1971. Effect of ethacrynic acid and chlorothiazide on intrarenal hemodynamics in normal man. Am. J. Physiol. 220: 482.

12. Ardaillou, R., P. Vuagnat, H. Kuntziger, and G. Richet. 1967. Excrétion d'eau libre en conditions d'antidiurèse sous l'effet de l'acide éthacrynique. Rev. Fr. Etud. Clin. Biol. 12 : 582.

13. Burg, M., J. Grantham, M. Abramow, and J. Orloff. 1966. Preparation and study of fragments of single rabbit nephrons. Am. J. Physiol. 210: 1293.

14. Burg, M., S. Helman, J. Grantham, and J. Orloff. 1969. Effect of vasopressin on the permeability of isolated rabbit cortical collecting tubules to urea, acetamide and thiourea. In Urea and the Kidney. Bodil Schmidt-Nielsen, editor. Excerpta Medica Foundation, Publishers, Amsterdam. 193.

15. Grantham, J. J., and J. Orloff. 1968. Effect of prostaglandin $E_{1}$ on the permeability response of the isolated collecting tubule to vasopressin, adenosine $3^{\prime}, 5^{\prime}$-monophosphate, and theophylline. J. Clin. Invest. 47: 1154.

16. Kokko, J. P. 1970. Sodium chloride and water transport in the descending limb of Henle. J. Clin. Invest. 49: 1838.
17. Schafer, J. A., and T. E. Andreoli. 1972. Cellular constraints to diffusion: the effect of antidiuretic hormone on water flows in isolated mammalian collecting tubules. J. Clin. Invest. $51: 1264$.

18. Orloff, J., and J. S. Handler. 1962. The similarity of effects of vasopressin, adenosine- $3^{\prime}, 5^{\prime}$-phosphate (cyclic $\mathrm{AM}$ P) and theophylline on the toad bladder. J. Clin. Invest. $41: 702$.

19. Orloff, J., and J. S. Handler. 1967. The role of adenosine $3^{\prime}, 5^{\prime}$-phosphate in the action of antidiuretic hormone. Am. J. Med. $42: 757$.

20. Grantham, J. J., and M. B. Burg. 1966. Effect of vasopressin and cyclic AMP on permeability of isolated collecting tubules. Am. J. Physiol. 211: 255.

21. Cobb, J. R., and T. J. McManus. 1966. Inhibition of neurohypophyseal hormone action by ethacrynic acid. Abstracts of the Third International Congress of Nephrology, Washington, D. C. 2 : 172.

22. Bentley, P. J. 1969. Actions of vasopressin and aldosterone on the toad bladder: inhibition by ethacrynic acid. J. Endocrinol. $43: 347$.

23. Jakobs, K. H., K. Schultz, and G. Schultz. 1972. Hemmung von Adenyl-cyclase-präparationen aus der Rattenniere durch Calciumionen und verschiedene Diuretica. Naunyn-Schmiedebergs Arch. Pharmakol. 273: 248.

24. Bittar, E. E., D. A. T. Dick, and D. J. Fry. 1968. The action of ethacrynic acid on sodium efflux from single toad oocytes. J. Physiol. 196: 693.

25. Dunn, M. J. 1970. The effects of transport inhibitors on sodium outflux and influx in red blood cells: evidence for exchange diffusion. J. Clin. Invest. 49: 1804.

26. Hoffman, J. F., and F. M. Kregenow. 1966. The characterization of new energy-dependent cation transport processes in red blood cells. Ann. N. Y. Acad. Sci. 137: 566.

27. Whittembury, G., and J. Fishman. 1969. Relation between cell $\mathrm{Na}$ extrusion and transtubular absorption in the perfused toad kidney: the effect of $\mathrm{K}$, ouabain and ethacrynic acid. Pfluegers Arch. Eur. J. Physiol. 307: 138.

28. Grantham, J. J., M. B. Burg, and J. Orloff. 1970. The nature of transtubular $\mathrm{Na}$ and $\mathrm{K}$ transport in isolated rabbit renal collecting tubules. J. Clin. Invest. 49: 1815.

29. Abramow, M. 1973. Study of tubular functions by microperfusion of isolated renal tubules. In Advances in Nephrology. Year Book Medical Publishers, Inc., Chicago. In press.

30. Charnock, J. S., and A. F. Almeida. 1972. Ethacrynic acid accumulation by renal tissue. Biochem. Pharmacol. $21: 647$.

31. Goldberg, M. 1966. Ethacrynic acid: site and mode of action. Ann. N. Y. Acad. Sci. 139: 443.

32. Cannon, P. J., R. P. Dell, and R. W. Winters. 1968. Effect of diuretics on electrolyte and lactate gradients in dog kidney. J. Lab. Clin. Med. 72: 192.

33. Atherton, J. C., M. A. Hai, and S. Thomas. 1968. The time course of changes in renal tissue composition during water diuresis in the rat. J. Physiol. 197: 429.

34. Orloff, J., H. N. Wagner, Jr., and D. G. Davidson. 1958. The effect of variations in solute excretion and vasopressin dosage on the excretion of water in the dog. J. Clin. Invest. $37: 458$. 